\title{
A Study of Komeito as a Critical Minority Party in Japanese Coalition Regimes
}

\author{
Ming-shan $\mathrm{Wu}$ \\ Department of Mass Communication, I-Shou University, Taiwan \\ E-mail:meizyou@isu.edu.tw \\ Chun-ta Lee (Corresponding author) \\ Department of Public Administration and Policy, National Taipei University, Taiwan \\ E-mail: chunda@gate.sinica.edu.tw
}

Received: April 13, 2011 Accepted: May 12, $2011 \quad$ doi:10.5539/ass.v7n9p9

\begin{abstract}
Ever since the Liberal-Democratic Party (LDP) invited the New Komeito (Komeito hereafter) to form a coalition cabinet in October 1999, the two political parties have maintained their partnership to date. The time and significance of LDP-Komeito cooperation are remarkable in Japanese politics. The general concept of "critical minority", referring to a small number of seats in the Japanese Diet, is necessary to a parliamentary majority. However, this paper argues the real significance of Komeito minority lies not in "post-election" but rather in "pre-election." In other words, Komeito requests supporters to vote LDP candidates, especially the candidates of the House of Representatives elected by small electoral districts, and hence help LDP become major party in both houses. The authors first review LDP's incentives of forming a coalition cabinet, and then discuss why LDP and Komeito are motivated to cooperate. Finally, the authors apply electoral data to analyze the practical effects of LDP-Komeito cooperation.
\end{abstract}

Keywords: Japan, Coalition, Critical minority, Komeito, Liberal-Democratic Party, LDP

After the general election to the House of Representatives on July 18, 1993, LDP lost its status as a majority in the parliament, signifying the end of the 38-year single-party government in Japan. The Morihiro Hosokawa coalition cabinet, which was composed by seven minor parties and one faction, took over the ruling power and since then Japan's political situation had entered the era of coalition regime. In January 1996, Prime Minister Tomiichi Murayama resigned unexpectedly and LDP president Hashimoto was appointed as the new Prime Minister. LDP regained power in the Diet, but Hashimoto still sworn in as the Prime Minister of a coalition government.

LDP has always been the largest party in Japan. Each of the LDP-led coalition cabinet seeks partnerships with different political parties but Komeito, a small political party, is always one of them. From the first LDP-Komeito coalition cabinet in 1999 to the latest cooperation terminated in 2009, there are six Prime Ministers and eighteen cabinet reshuffles, and the cooperation between the two parties has always been sustained and stable.

\section{The Existing Arguments and Research Questions}

The main purpose of this article is to answer two questions. First, why did LDP always invite Komeito to form a coalition cabinet? And second, could the general concept of "critical minority" be completely used to explain the Komeito's role in LDP-Komeito coalitions? In the following discussions, we first introduce the existing arguments of minority role in coalition governments, and then indicate the difference between Japan's political particularities and the existing perspectives.

\subsection{The Existing Arguments}

Wang (2001: 11-13) points out that "intrinsic motivation" and "instrumental motivation" are two incentives for (small) political parties to join a coalition cabinet. Intrinsic motivation is also known as "office-seeking pattern" which puts emphasis on parties' interests to maximize the political values of cabinet portfolios in return. In order 
to ensure the highest values of gaining positions in a cabinet, the main ruling party would expect to the minimum of political parties in a coalition government. According to the concept of intrinsic motivation, the most adequate legislative member size of a coalition cabinet is barely more than half which minimizes the bargaining cost of portfolio distribution. Given to that concept, a major party can only cooperate with a few minor parties when looking for coalition partnerships. Believing in intrinsic motivation, William H. Riker advanced a model of "Minimal Winning Coalition (MWC)" extended from rational choice theory (Riker, 1962).

On the other hand, when parties seek for policy-implementation instead of gaining government portfolios, instrumental motivation (policy-seeking pattern) put emphasis on the results of public policies and look for political parties with shared values and compatible-ideology (Warwick, 1994).

\subsection{Compatibility and Distinction}

Komeito was invited to join the LDP-Liberal coalition on October 5, 1999, when it was necessary to pass an act "Law Concerning Situation in Areas Surrounding Japan" under America's pressure. The LDP-Liberal coalition was already the majority in the House of Representatives, but with regard to the House of Councilors, they were eager to gain Komeito's support. The Komeito's role in the House of Councilors can be regarded as "critical minority," and this corresponds to "intrinsic motivation" as Komeito exchanged support for a ministerial portfolio (of Land, Infrastructure, Transport and Tourism). However, there are still many cases that the two existing patterns of office-seeking and policy-seeking can not explain completely why LDP and Komeito decide to cooperate with each other.

\subsubsection{Distinctions from Office-seeking Pattern}

The legislative structure in Japan is bicameralism. Article 59 of Japan's Constitution states "(1) A bill becomes a law on passage by both Houses, except as otherwise provided for by the Constitution. (2) A bill, which is passed by House of Representatives, and upon which House of Councilors makes a decision different from that of House of Representatives, becomes a law when passed a second time by House of Representatives by a majority of two-thirds or more of the members present. (3) The provision of the preceding paragraph does not preclude House of Representatives from calling for the meeting of a joint committee of both Houses, provided for by law. (4) Failure by House of Councilors to take final action within sixty days after receipt of a bill passed by House of Representatives, time in recess excepted, may be determined by House of Representatives to constitute a rejection of the said bill by House of Councilors." Given to those provisions, a governing party needs to maximize representations in both houses in order to pass laws.

However, there are two exceptions that exceed predictions of MWC model. The first case is "LDP-Komeito-Conservative" coalition. From Yoshiro Mori cabinet to secondary Junichiro Koizumi cabinet, there are eight coalition cabinets cooperating with Komeito and the Conservative Party (which renamed as the New Conservative Party in December 2002). Table 1 shows the number of LDP and Komeito's representatives in both houses. LDP had already been the majority but still formed an "oversized coalition", which probably brought about the loss of portfolio payoffs.

The second case is LDP-Komeito coalition formed after the House of Councilors election in 2007. After the election, the total seats of LDP and Komeito are 103, less than half of total seats (121). However, Prime Minister Abe eventually decided to reshuffle the cabinet, then kept cooperating with Komeito on August 27, 2007, and appointed Tetsuzo Fuyushiba, a politician of Komeito, as Minister of Land, Infrastructure, Transport and Tourism.

The aforementioned description reveals that neither a single-party government led by LDP nor a LDP-Komeito coalition cabinet own more than the half of total seats in the House of Councilors. Accordingly, the decision made by LDP to cooperate with Komeito is hardly to explain, yet giving out an important ministerial portfolio as exchange does not match with the perspective of intrinsic motivation. That is to say, these cases are incompatible with the intrinsic motivation and MWC model Riker developed.

Bicameralism in Japan is characterized as superiority of the House of Representative, which also lead to a discussion on "House of Councilors Useless" (Hajime, 2004; Masaji, 2005: 87-92). To the point of this research, the "House of Councilors Useless" brings about a delusion that the majority of House of Representatives can easily pass a bill without any support of House of Councilors. That is to say, the formation of Abe cabinet (LDP-Komeito coalition) which merely controls majority in the House of Representatives corresponds to the perspective of intrinsic motivation. However, the legislative role that House of Councilors plays is surely not only a rubber stamp. An opposition party can delay bills by manipulating the legislative sequence when Procedure Committee in House of Councilors is under control. Additionally, House of Councilors, according to 
the Constitution, also can table a bill for sixty days. Most important of all, the principle of "discontinuous sessions" (Makoto, 2003: 48) in Japan's parliament refers that an unfinished bill has to be presented again in the next session. As a result, House of Councilors is as much important as House of Representatives in Japanese legislative politics. If a ruling party or a ruling coalition tries to pass a bill without a hitch, the best way is to earn majority support from both houses at the same time.

\subsubsection{Distinctions from Policy-seeking Pattern}

The left-right confronting axis between the Socialist Party and the LDP under the so-called "1955 System" puts bounds to the consequent development of Japan's party ideology. (Note 1) Komeito was self-defined as a "median-way" party when founded on November 17, 1964 (Hideo, 1999: 11; Sadao, 2005: 223-241). Although "median-way" Komeito and "right-leaning" LDP are much ideologically alike and accommodate with certain policies, there are some policy divergences between the two parties during the process of coalition, such as their stances on Japan's Constitution amendment, US-Japan joint Security Alliance, and education and National Annuity reformation are not identical. Furthermore, LDP-Komeito coalition never proposes a joint manifesto in periods of electoral competition during cooperation governance.

Confronting arguments between the two parties can be witnessed through the following cases. First, an evident disagreement between LDP and Komeito is about constitution reformation. LDP advocates framing a whole new Japanese Constitution, but Komeito prefers to amend or supplement the present Constitution. LDP argues that the existing Japanese Constitution was directed by the United States and Japan was forced to approve it reluctantly. As a result, LDP claimed a "Draft of New Japanese Constitution" on November 22, 2005 while celebrating its fiftieth anniversary of establishment since 1955. On the other hand, Komeito advocates maintaining current constitutional structure while supplementing certain modern ideas such as environment privilege, privacy privilege, intellectual property rights, and so on. In short, the way Komeito resorts to is "kaken" (enriching the constitution) (Keizou, 2007: 70-71; Watanabe Osamu, 2007: 47).

The second case is related to "Treaty of Mutual Cooperation and Security between the United States and Japan". LDP agrees that the goal of US-Japan joint Security Alliance is to ensure peace of Japan and Asia-Pacific. To put the Treaty into practice, Japan has to strengthen self-defense capabilities. Besides, LDP endorses Japan's collective self-defense forces (Akira, 2001) and constitutionality of "Japan Self Defense Forces (JSDF)". Komeito, however, emphasizes the "defense" essence of US-Japan joint Security Alliance and asks to enforce Article 9 which strictly limits Japan's self-defense forces. Komeito promotes to reduce armaments and requires to transfer 20\% of Official Development Assistance Budget to "Human Safety Protection" (Tehranian \& Ikeda, 2006: 239-265).

Furthermore, education reformation also contrasts sharply between the two parties. LDP emphasizes civism, community, nationalism, and patriotism, while Komeito looks forward to legally subsuming patriotism into education policies. The fourth case is about National Annuity reformation. The two parties all claim "the national treasure should bear more expense of National Annuity and the proportion should enhance from one-third to half," which was also written in separate Manifestos during the House of Representatives election in 2003. However, LDP evades the discussion of the inevitable problems related to the national budget while Komeito urges a concrete policy. Komeito advises abolishment of rated tax to income in order to raise financial resource of National Annuity, a policy which might increase middle-high income citizens with heavier tax burdens. As LDP's supporters are mainly middle-high taxpayers (Politics Dept., The Yomiuri Shimbun, 2005: 63), Komeito's claim is obvious bound to undermin LDP's support.

In sum, discrepancies between two parties include constitutional structure, policy of US-Japan joint Security Alliance, education and citizen livelihood in broad and common aspects, proving that the two parties disagree on many issues.

\section{The Motivations for LDP-Komeito Coalition}

Office-seeking pattern and policy-seeking pattern are not sufficient to elaborate on LDP-Komeito collaboration. The two theoretical patterns are mainly based on post-election and confirmable conditions, such as number of parties, legislative seats, executive appointments, and policy reconciliation. Strom (1990: 70) proposed two explanations of strategic election to analyze why a minority regime exists. First of all, an opposition party is more eager to utilize its legislative potential to guide policies than to be a ruling partner. Though it is inevitable for an opposition party to exchange policy concessions in return for executive portfolios, to formulate an ambiguous but irresponsible policy may hurt the party's image advertising. The other consideration is electoral calculation for individual parties. An opposition party may refuse to join in a coalition cabinet for maintaining its electoral competitiveness. 
In this paper, we argue that LDP-Komeito coalition is the result of "pre-election" calculations which is different from previous discussion. While LDP and Komeito disagree with many ideas in electoral competition, they both desire to acquire or raise individual votes and Diet seats. LDP's main pursuit is its political predominant role in Japan which based on successful pre-election negotiations and consequent coalition governances. On the other side, Komeito promises to "Soka Gakkai" (a religious group attaching to Komeito firmly) and aspires to policy implementation. In order to fulfill individual intentions, LDP and Komeito primarily reach a deal on seat-winning presupposition before election.

\subsection{LDP's Dilemma}

During the late 1980s, LDP suffered a sequence of monetary scandals and consequently lost a lot of public support. In addition, two social changes lead to the breakup of support for LDP.

\subsubsection{The Boost of Newborn Parties}

Under the 1955 System of LDP's one-party dominance, there seemed to be only one option for citizens who psychologically reject Socialist Party and Japan Communist Party. However, when coalition governance took place in 1993, many non-Socialism parties were rose and LDP lost its vote steadiness and the advantage of being a big party.

Among new parties, Democratic Party is the most threatening competitor to LDP. The enlargement of Democratic Party is extensive that there is a wide spectrum of new members from left-wing to right-wing parties. Moreover, three of five former Presidents of Democratic Party are used to be the members of LDP (including Hatoyama Yukio, Okada Katsuya and Ichiro Ozawa), and Kan Naoto, one of its party establishers, even served as a Minister of Ministry of Health, Labor, and Welfare in LDP Hashimoto government. As a result, Democratic Party was not only similar to LDP in policy orientation, but also undermine part of LDP's political support.

\subsubsection{Chronic Economic Depression}

Under the 1955 System, LDP mainly relied on "soshikihyou" (hard votes) and was supported by exceeding 500 industrial groups in Japan (Akira, 2003: 88-89). Karel van Wolferen (1990: 123-131), a Dutch journalist, has ever observed Japan's industrial network and marveled at its sophistication. The offer of tax-cut, subsidy and public expenditure by LDP are made for the industrial groups to exchange "hard votes" and political contribution (Calder, 1983). The tradeoff was marked by the "Iron Triangle" (inter-benefit structure among politicians, industries and bureaucrats) which consolidates electoral support for LDP and helps to get more donations in return (Kenji, 2002: 133).

The existence of Iron Triangle under the 1955 System is based on highly prosperous economic condition in Japan and the steady governance. However, as the end of 1955 System, the burst of the economic bubble depressed Japan and then a long-term economic recession ensued. The coalition cabinet led by LDP tried to extend domestic demands and to stimulate economic prosperity, while spending deficit and nation debt were raised contrarily. These desperate straits diminished LDP's political contributions and undermined the support from the public.

\subsection{Komeito's Dilemma}

\subsubsection{Electoral Defeat in the House of Representatives}

Komeito's crisis in the House of Representatives is mainly from 1994 reformation of electoral system, entitled "The Mixed System of Single-Member and Proportional-Representation Districts." The new electoral system puts emphasis on single-member district and tends to damage small parties (Jiro, 1998: 168-186; Toshihiko, 1997: 15-21).

Therefore, Komeito's legislative seats decrease to a large extent. When the new electoral system of Representatives election was put into practice for the first time in 1996, the number of Komeito's Representatives declined from 51 to 42 ; and in 2000, only 31 of 74 candidates nominated by Komeito were elected. This reveals that Komeito was marginalized when competing against two large parties, LDP and Democratic Party.

\subsubsection{Defeat in Amendment to Electoral Law}

After joining in ruling coalition, Komeito actively promoted an "Amendment to Electoral Law," in which the idea of two-candidate and three-candidate districts is proposed, and it is advantageous to small parties. (Note 2) However, increase of seats for a party definitely deprives others' opportunities. As a result, Amendment to Electoral Law was rejected by other parties, including Democratic Party, Liberal Party, Social-Democratic Party and Japan Communist Party. (Note 3) Meanwhile, the amendment does damage LDP's vote share, and some members of LDP surely disagree with it. (Note 4) 


\subsection{Context and Model of LDP-Komeito Coalition}

As participating in LDP-Liberal coalition on October 5, 1999, Komeito signed a "LDP-Liberal-Komeito Coalition Contract" which clearly pointed out the three parties would negotiate with each other on issues of candidate nomination in single-member district before next General Election (Tatsuhiko, 1999: 1). The contract was aimed to strengthen the coalition through pre-election coordination; however, Liberal Party decided to back out of the deal and coalition on April 1, 2000, when Liberal Party and LDP debated bitterly about the "reduction of 20 seats in Proportional-Representation System" (Kenya, 2005: 80-91; Public Opinion Survey Dept., The Yomiuri Shimbun 2004: 116). Although LDP-Liberal-Komeito electoral coalition ended with the absence of Liberal Party, LDP and Komeito still carried on their electoral coalition in 42th General Election. With the beginning of the first electoral coalition on July 25, 2000, LDP and Komeito had cooperated in the House of Representatives election and in the House of Councilors election respectively for three times.

Since there are differences between the two electoral systems (Table 2), coalition patterns of LDP-Komeito in the two chambers differ as well. First of all, House of Representatives adopts "The Mixed System of Single-Member and Proportional-Representation Districts." In some parts of single-member districts, LDP and Komeito negotiate with each other and decide not to nominate individual candidate in the same voting precincts. Besides, they even require their supporters to cast ballots for candidates nominated by the other party. In proportional-representation districts, although two parties provide their own party-lists respectively, LDP voluntarily requires their firm supporters, such as Koenkai (local support groups), to vote for those on the party-list that Komeito presents (Souichirou, 2007: 69).

Secondly, House of Councilors adopts the "Mixed System of Multi-Member and Proportional-Representation Districts" since 1983. In parts of proportional-representation districts, LDP and Komeito do not align but nominate candidates respectively; while in parts of multi-member districts, Komeito nominates strategically according to the district magnitude. When a district is larger than two, Komeito nominates a candidate to "compete and coexist" with LDP. However, in a district with only one or two Councilors-elect, Komeito will give precedence to LDP.

\section{Effects of LDP-Komeito Electoral Coalition}

During the electoral coalition process, Komeito is always a critical minority because Komeito's "soshikihyou" has a profound effect on LDP. In other words, although Komeito controlls the relatively minor legislative seats, it provides sacrifices and assistance for LDP in elections and contribute greatly to LDP-Komeito coalition cabinet.

\subsection{Electoral Coalition Effects on House of Representatives}

Electoral results in the House of Representatives always determinate who dominate the government. That is to say, if LDP and Komeito agree with sharing values and nominate candidates abstemiously in advance, they can win the majority of legislative seats and equip them to form a coalition cabinet.

\subsubsection{Advances of Vote Share and Seat Share}

In single-member districts, Komeito appeals to voters for supporting LDP candidates when nominations are absent and contrariwise. For example, LDP's vote share is $74.5 \%$ (120 of 161 candidates) in 2000 and then keeps moving upward in 2003 and 2005, 80.8\% (160 of 198) and 93.7\% (224 of 239) respectively. At the same time, Komeito's seat share is $64.3 \%$ ( 9 of 14) in 2000 and then climb upward in 2003 and 2005, 90\% (9 of 10) and $88.8 \%$ ( 8 of 9) respectively. According to Yomiuri Shimbun's exit polls, LDP and Komeito are getting closer in vote share in single-member districts. In districts without Komeito candidates, the proportion of LDP supporters who claim to vote for Komeito raises from $61 \%$ in $2000,72 \%$ in 2003 to $78 \%$ in 2005. On the contrary, in districts without LDP candidates, the proportion raises from 38\%, 56\% to $68 \%$ (Politics Dept., The Yomiuri Shimbun, 2005).

According to their exit poll, Ikuo and Tuka (2004: 93) discuss Komeito's "soshikihyou" that LDP relies on and provide some arguments. If $60 \%$ of voters who support Komeito in proportional-representation district cast their votes for LDP, it would be possibly for 34 candidates of LDP single-member-district to avoid failing in 2000 and 53 candidates in 2003 . On the other hand, if the support rate increases to $80 \%$, the candidates who avoid fail would raise to 44 in 2000 and 77 in 2003 (Ikuo, 2006: 376).

Zenichirou (2003: 46) compares votes of two electoral systems, single-member district and proportional-representation district, and he discerns a huge gap between the two. The electoral result in 2003 reveals that Komeito was supported by 8.73 million voters in PR district while only 0.89 million voters in single-member district. Surprisingly, the difference between two systems was about 7.84 million. According to Yomiuri Shimbun's exit poll report, almost $72 \%$ of voters who supported Komeito cast their ballots for LDP in 
single-member districts. This implied that one-fifth of the whole LDP votes in single-member districts were from Komerto's supporters.

In terms of NHK's exit poll report, Souichirou (2007: 70-71) points out the reason that LDP won a landslide victory in 2005 is more about the benefit of electoral coalition alignment with Komeito. The report revealed $75 \%$ of Komeito supporters cast their ballots for LDP candidates in single-member districts. Without Komeito's support, LDP might lose 55 seats in the House of Representatives. Furthermore, if the total votes of Komeito went to Democratic Party, there would be a decrease of 72 legislative seats in LDP, and the party would lose its advantage of majority over other parties. Lastly, in the districts where the LDP-Komeito coalition did not work together, only $56.9 \%$ ( 29 of 51 ) LDP candidates won and the percentage lagged far behind $93.7 \%$ in districts with Komeito's cooperation.

\subsubsection{Effects on Votes and Vote Share}

Table 3 shows the effects on votes and vote share of LDP-Komeito coalition. Ever since two parties had cooperated in some of the single-member districts, DLP's votes and vote share grew by degrees. In 1996 before the coalition had been carried into execution, LDP won 21,839,096 votes (38.62\%). After aligning with Komeito, LDP attracts more public support acquiring $24,945,806$ votes $(40.97 \%)$ in $2000,26,089,326(43.85 \%)$ in 2003 , and 32,518,389 (47.77\%) in 2005.

On the other hand, LDP offered Komeito large number of hard votes in proportional-representation districts in return; hence LDP got fewer votes in 2000 than in 1996 since the coalition had been carried out. Nevertheless, LDP still acquired more votes and vote share in 2003 and 2005 because of a unique political atmosphere-Prime Minister Koizumi Whirl. Before general election in 2003, Prime Minister Koizumi recommended Abe for the post of LDP's Secretary General, in which he earned much public admiration and support. According to Japan Business News' survey on September 23, support for Koizumi government raised from $48 \%$ to $65 \%$ and there were $75 \%$ supporters who approved the commission of Abe as LDP's Secretary General. On the other hand, Prime Minister Koizumi adopted a series of electoral strategies, such as "female assassin" candidates in 2005 general election (Harukata, 2006: 231-236).

Although there were no respectable growth on Komeito's vote share and seat share after coalition with LDP, it is commendable that a minor party, such as Komeito, exists and competes with the major party which benefits more from the new electoral system. In sum, with the decline of other minor parties, such as Social Democratic Party, it is the LDP-Komeito coalition effects for Komeito to retain a position in Japanese politics.

\subsection{Electoral Coalition Effects on House of Councilors}

House of Councilors in Japan has no privileges to raise a vote of confidence and a government is unable to request dissolution of House of Councilors. In the process of governing, House of Councilors may not play an influential role as House of Representatives does, and the electoral results of House of Councilors are not crucial to the government's formation and termination. It remains important for the evaluation of government's policy, and the electoral results of House of Councilors provide a base to examine LDP-Komeito coalition.

Based on the preceding descriptions, when a district magnitude is lager than two, Komeito always nominates a candidate to compete and coexist with LDP; however, in a district with only one or two Councilors-elect, Komeito will avoid nomination. In other words, LDP-Komeito electoral "coalition" in a district with LDP nominators only indicates Komeito's unilateral assistances. In districts with Komeito's assistances, LDP won 29 seats (out of 35 nominators) in 2001 and 28 seats (out of 42 nominators) in 2004. However, Souichirou argues that without Komeito's help, LDP would lose 3 Councilors in 2001 and 6 in 2004 (Souichirou, 2007: 96-97).

Komeito also acquires its deserving rewards. For example, with LDP's aids, Komeito won 8 proportional-representation seats in 2004 and the 8th seat was won by a narrow margin. The Komeito Councilor who elected from proportional-representation district and ranked on the 8th position won 1,077,658 votes, which exceeded Democratic Party's last Councilor-elect in mere 166,298 votes. Finally, we can also analyze coalition effects on elections from a negative perspective. There were a series of troubles happened to Abe government, such as the improper speech of Minister of Health and Welfare on women's position, and a suicide matter of Minister of Agriculture, Forestry and Fisheries due to monetary scandal. Since Komeito is a party focused on improving human right and honesty with upright politics, the proceeding troubles undoubtedly brought about paradoxes between the two parties. The common grounds and consensus of LDP-Komeito coalition had been eroded. In the House of Councilors election in 2007, only 6\% of LDP's supporters and 2\% of Komeito's supporters vote for the other party. (Note 5) 


\section{Conclusion}

The ultimate goal a political party pursues is to hold the reins of government and to retain or raise party share of legislative seats. While legislative majority are not controlled by a single party, there are no choices but to form a coalition cabinet. Because of the dissolution of public support for LDP, Komeito provides LDP with stable and reliable electoral votes to maintain LDP's political dominance and to ensure that LDP-Komeito coalition survive. That is to say, Komeito not only provides reliable hard votes for LDP, but also persuades their supporters to vote for LDP candidates through a rational process of negotiation with LDP.

With the help of coalition, Komeito maintains its power in legislature and carry out its electoral promises written on Party Manifesto. The official website of Komeito claims in detail that they have achieved $98 \%$ fulfillment of 123 social and welfare policies by legislative practices. (Note 6) Probably, Komeito exaggerate its policy success, but what really matters is that supporters approved its political option of cooperation with LDP. According to Japanese Business News public poll, $81 \%$ of Komeito supporters agree with LDP-Komeito coalition, and the proportion is above 37\% among LDP's supporters (Japan Business News, 2004). In addition, with the participation of coalition regimes, Komeito takes into consideration of Humanism in the US-Japan joint Security Alliance. It's an issue for the two parties to hold absolutely opposite views.

There might be huge ideological differences between the two parties, and hence result in different policy practices. LDP and Komeito never propose a Joint Manifesto during the past elections. However, with the experiences of cooperation, LDP regards Komeito's as indispensable for the reins of government. In House of Councilors election in 2007, LDP performed poorly without Komeito's cooperation, which reflects Komeito's importantance. Democratic Party's former President Naoto Kan had sarcastically claimed that LDP and Komeito should merge together and be renamed as "Convergent New Party" (Takao, 2004: 130). Given to Kan's statement, we can easily observe the intimate connection between two parties after the practice of electoral coalition.

\section{References}

Akira, N. (2001). Article 9th shocks postwar politics: Confidence and strength of the cabinet legislation bureau. Tokyo, Japan: Chuokeizai-Shi, Inc.

Calder, K. E. (1989). Zimintoutyoukiseiken no kenkyuu: kiki to hozyoukin. The study on LDP's extended governance: Crisis and subsidy. Tokyo, Japan: Bungei Shunju.

Hajime, M. (2004). Sanngiinseidoron: Sono sennkyoseido, teisuukakusamonndai, sosite sanngiinmuyouron ni tuite. House of Councilors: Electoral institution, votes weight-gap and the debate of House of Councilors' worthlessness. Tokyo, Japan: Tokyotosho Co., Ltd.

Harukata, T. (2006). Syusou sihai: Nihonnseizi no hennbou. Prime Minister dominance: Changes in Japan politics. Tokyo, Japan: Chuokoron-Shinsha, Inc.

Hideo, O. (1999). Nihonnseizi no tairituzuku: 93 nen ikou no seikaisaihen no naka. The confronting axis of Japan's politics: Political re-organization after 1993. Tokyo, Japan: Chuokoron-Shinsha, Inc.

Ikuo, K. (2006). Senngo nihonnseizi no kiseki: Ziminntousisutemu no keisei to hennyou. The trajectory of postwar Japanese politics: LDP's formation and changes. Tokyo, Japan: Iwanami Shoten.

Ikuo, K. \& Tuka, K. (2004). Koumei ga dotira wo erabu ka de seikenn ha kawaru. The turnover of the government: Determined by Komeito. Central Review, 1: 90-99.

Jiro, Y. (1998). Seizikaikaku. Political reform. Tokyo, Japan: Iwanami Shoten.

Keizou, N. (2007). Abe syusyou no higannitassei no tame no kenpou kaisei seikyoku ga hazimatta. Prime Minister Abe starts a desirable constitution reformation. Ekonomisito, May 29: 70-71.

Kenji, O. (2002). Seiziseido no sikumi. The structure of political institutions. Tokyo, Japan: Natsumesha Co., Ltd.

Kenya, M. (2005). Yamisyougunn. Backstage general. Tokyo, Japan: Kodansha Publishing Co., Ltd.

Makoto, O. (2001). Gikaihou. Diet Law. Tokyo, Japan: Yuhikaku Publishing Co., Ltd.

Masaji, K. (2005). Kokkai singi no kinou to hyouka ni kannsuru. The analysis of Diet's functions and evaluations. Gikaiseizikenkyuu, 75: 87-92.

Michisada, H. (1983). Hozyoukin to seikentou. Subsidy and ruling party. Tokyo, Japan: Asahi Shimbun Publishing Co.

Mikitaka, M. (2003). Gikaisieto to nihonseizi. Electoral systems and Japan's politics. Tokyo, Japan: 
Bokutakusha.

Osamu, W. (2007). Kenpou kaisei mondai wo saninnsen de syoumen kara gironnseyo. House of Councilors should take charge of discussion in constitutional reform. Ekonomisuto, June 26: 47-47.

Politics Dept., The Yomiuri Shimbun. (2005). Zimintou wo kowasita otoko koizumi seikenn 1500 niti no sihinzitu. The reality of collapse during 1,500 reining days of LDP Koizumi government. Tokyo, Japan: Shinchosha Co., Ltd.

Public Opinion Survey Dept., The Yomiuri Shimbun. (2004). Nidaiseitou zidai no akebono: heisei no seizi to sennkyo. The monster of two-party system: Politics and elections in Heisei period. Tokyo, Japan: Bokutakusha.

Sadao, H. (2005). Koumeitou, soukagakkai to nihonn. The Komeito, Soka Gakkai and Japan. Tokyo, Japan: Kodansha Publishing Co., Ltd.

Souichirou, K. (2007). Senkyokyouryoku to mutouha. Election coalition and median voter. Tokyo, Japan: Japan Broadcast Publishing Co., Ltd.

Strom, K. (1990). Minority government and majority rule. New York: Cambridge University Press.

Takao, I. (2004). Zikou rennritu no naka de usinawareta seiken no aidennthithi. The vanishing identity with ruling power in LDP-Komeito coalition. Central Review, 9: 129-133.

Tatsuhiko, Y. (1999). Obuti seiken no keizai seisaku. Obuchi government's economical policies. Tameike, 35 : 1.

Tehranian, M. \& Ikeda, D. (2006). The choices for 21st century, trans. Chen Peng-jen. Taipei, Taiwan: Cheng Yin Culture.

Toshihiko, N. (1997). Syousenkyoku-hireidaihyousei no mondaiten. The probable problems of the single-member district and PR party lists parallel system. Yuhikaku, 1106: 15-21.

van Wolferen, K. (1990). Nihon/kenryoku kouzou no nazo. The mystery of power structure in Japan, trans. Shinohara Masaru. Tokyo, Japan: Hayakawa Publishing Corporation.

Warwick, P. (1994). Government survival in parliamentary democracies. Cambridge, UK: Cambridge University Press.

Yeh-lih, W. (2001). The study on the coalition typology and causations. In Su Yeong-ching (Eds.), coalition cabinet: Is it a new choice for Taiwan's democratic Regime? (pp. 3-32). Taipei, Taiwan: New Taiwanese Cultural Foundation.

Zenichirou, T. (2003). Seiken koudai kanouna nitousei ni mada natteinai. Two-party system promoting regime turnover is not set yet. Ekonomisuto, December 23: 44-47.

Zenichirou, T. (2005). Nihon no sousennkyo: 1946-2005. The general elections in Japan: 1946-2005. Tokyo, Japan: Tokyo University Publishing.

\section{Notes}

Note 1. The term means that LDP had dominated the Japanese politics since 1955 until 1993 which lost its majority position in House of Representatives.

Note 2. (2001, October 25). Touri ga subete? Gourisei ga miezu. Party interests are primary but without public rationale? Asahi News p. 4.

Note 3. (2004, July 5). Nozomashi seikenn, zikourennritu 20\% kyuutraku. The ideal reins of government: Support for LDP-Komeito coation falls 20\% sharply. Japan Business News, p. 3.

Note 4. (2001, October 31). Syuugiin hukusuuku sousetuan ziminhanpatu de sakiokuri. The initiative of House's multi-members electoral system: Suspended by LDP's opposition. Asahi News, p. 3.

Note 5. (2001, July 30). Abe hushinnin senmei honsya deguti tyousa. The exit poll reveals distrust to Prime Minister Abe raise. Asahi News, p. 1.

Note 6. Komeito, (2008). Seisaku, ziseki. Policies and practices. [Online] Available: http://www.komei.or.jp/ (February 8, 2008) 
Table 1. Coalition cabinets in Japan (1993 2007)

\begin{tabular}{|c|c|c|c|}
\hline No. & Prime Minister and Gov. & Formation Date & Coalition Parties \\
\hline 79 & Morihiro Hosokawa (JNP) & 1993.08 .09 & JNP, SP, JRP, NK, DSP, NPS, USD, UDR \\
\hline 80 & Tsutomu Hata (JRP) & 1994.04.28 & JRP, LP, DSP, NK, JNP, USD, UDR \\
\hline \multirow{2}{*}{81} & Tomiichi Murayama (SP) & 1994.06.30 & SP, NPS, LDP \\
\hline & Reshuffle & 1995.08 .08 & SP, NPS, LDP \\
\hline 82 & Ryutaro Hashimoto I & 1996.01 .11 & LDP, SP, NPS \\
\hline \multirow{2}{*}{83} & Hashimoto II & 1996.11.07 & \begin{tabular}{|llllll} 
LDP (SP and NPS are outside-cooperative with \\
government)
\end{tabular} \\
\hline & Reshuffle & 1997.09.11 & \begin{tabular}{|lllll} 
LDP (SP and NPS are outside-cooperative with \\
government)
\end{tabular} \\
\hline \multirow{3}{*}{84} & Keizo Obuchi & 1998.07 .30 & LDP \\
\hline & First Reshuffle & 1999.01 .14 & LDP, LP \\
\hline & Second Reshuffle & 1999.10.05 & LDP, LP, NK \\
\hline 85 & Yoshiro Mori I & 2000.04 .05 & LDP, NK, CP \\
\hline \multirow{3}{*}{86} & Mori II & 2000.07 .04 & LDP, NK, CP \\
\hline & First Reshuffle & 2000.12 .05 & LDP, NK, CP \\
\hline & Second Reshuffle & 2001.01 .06 & LDP, NK, CP \\
\hline \multirow{3}{*}{87} & Junichiro Koizumi I & 2001.04 .26 & LDP, NK, CP \\
\hline & First Reshuffle & 2002.09 .30 & LDP, NK, CP \\
\hline & Second Reshuffle & 2003.09 .22 & LDP, NK, NCP \\
\hline \multirow{2}{*}{88} & Koizumi II & 2003.11 .19 & LDP, NK, NCP \\
\hline & Reshuffle & 2004.09 .27 & LDP, NK \\
\hline \multirow{2}{*}{89} & Koizumi III & 2005.09 .21 & LDP, NK \\
\hline & Reshuffle & 2005.10 .31 & LDP, NK \\
\hline \multirow{2}{*}{90} & Shinzo Abe (LDP) & 2006.09 .26 & LDP, NK \\
\hline & Reshuffle & 2007.08.27 & LDP, NK \\
\hline \multirow{2}{*}{91} & Yasuo Hukuda (LDP) & 2007.09 .26 & LDP, NK \\
\hline & Reshuffle & 2008.08 .02 & LDP, NK \\
\hline
\end{tabular}

Source: Authors.

Notes:

1. Initials: JNP for Japan New Party; SP for Socialist Party; JRP Japan Renewal Party; NK for New Komeito; DSP for Democratic Socialist Party; NPS for New Party Sakigake; USD for Union of Social Democracy; UDR for Union of Democratic Reform; LP for Liberal Party; LDP for Liberal-Democratic Party; CP for Conservative Party; NCP for New Conservative Party.

2. Total seats of House of Representatives: 500 in 1996, 480 in 2000 and then; total seats of House of Councilors: 252 in 1998, 247 in 2001, 242 in 2004 and then.

Table 2. Comparisons between Electoral System of House of Representatives and of Councilors

\begin{tabular}{|c|c|c|c|}
\hline & & House of Representatives & House of Councilors \\
\hline \multicolumn{2}{|c|}{ Japanese Wording } & General Election & Ordinary Election \\
\hline \multicolumn{2}{|c|}{ Legislative Term } & 4 Years & 6 Years \\
\hline \multicolumn{2}{|c|}{ Seats for Reelection } & Whole Representatives & $\begin{array}{l}\text { One-half Councilors Are Elected } \\
\text { Every } 3 \text { Years }\end{array}$ \\
\hline \multirow{2}{*}{\multicolumn{2}{|c|}{$\begin{array}{c}\text { Dissolution by Prime Minister } \\
\text { Candidate Qualification for Age }\end{array}$}} & Yes & No \\
\hline & & Over 25 Years Old & Over 30 Years Old \\
\hline \multicolumn{2}{|c|}{ Electoral System } & $\begin{array}{l}\text { The Mixed System of } \\
\text { Single-Member } \\
\text { Proportional-Representation } \\
\text { Districts }\end{array}$ & $\begin{array}{lr}\text { The Mixed System } & \text { of } \\
\text { Multi-Member } & \text { and } \\
\text { Proportional-Representation } & \\
\text { Districts } & \end{array}$ \\
\hline \multicolumn{2}{|c|}{ Total Seats } & 480 & 242 \\
\hline \multirow{2}{*}{$\begin{array}{l}\text { How Distribute } \\
\text { Seats? }\end{array}$} & $\begin{array}{l}\text { Ordinary } \\
\text { Districts }\end{array}$ & $\begin{array}{lccc}300 & \text { Seats } & \text { for } & 300 \\
\text { Single-Member Districts } & \\
\end{array}$ & $\begin{array}{l}146 \text { Seats for } 47 \text { Multi-Member } \\
\text { Districts }\end{array}$ \\
\hline & PR Districts & $\begin{array}{l}180 \text { Seats for } 11 \text { Geographic } \\
\text { Districts }\end{array}$ & 96 Seats for One National District \\
\hline
\end{tabular}




\begin{tabular}{|c|c|c|c|}
\hline \multirow{2}{*}{ How Cast? } & $\begin{array}{l}\text { Ordinary } \\
\text { Districts }\end{array}$ & For a Candidate & For a Candidate \\
\hline & PR Districts & For a Party & For a Party or a Candidate \\
\hline \multirow[b]{2}{*}{ Legislators-Elect } & $\begin{array}{l}\text { Ordinary } \\
\text { Districts }\end{array}$ & $\begin{array}{l}\text { A Candidate Who Earns the } \\
\text { Most Votes }\end{array}$ & $\begin{array}{l}\text { Candidates Who Earn the Most } \\
\text { Votes }\end{array}$ \\
\hline & PR Districts & $\begin{array}{l}\text { 1. Distributing Seats to } \\
\text { Parties by Vote-share. } \\
\text { 2. Candidates Are Ordered by } \\
\text { Party-list, but Two or More } \\
\text { Candidates May Sit on the } \\
\text { Same Placings. } \\
\text { 3. Confirming by the } \\
\text { Principle of "First Loser } \\
\text { Margin"*. }\end{array}$ & $\begin{array}{ll}\text { 1. } & \text { Total Party Vote-share }= \\
\text { Candidate Personal Votes }+ \\
\text { Party Votes. } \\
\text { 2. } \\
\text { Distributing Seats According } \\
\text { to Party Total Vote-share } \\
\text { 3. Confirming by Candidates } \\
\text { who earn the Most Votes on } \\
\text { Party-list (Open-list PR). }\end{array}$ \\
\hline \multirow{3}{*}{$\begin{array}{l}\text { When Will Hold } \\
\text { a By-election? }\end{array}$} & $\begin{array}{l}\text { Ordinary } \\
\text { Districts }\end{array}$ & Any Representative is Absent & One-fourth Councilors are Absent \\
\hline & PR Districts & $\begin{array}{l}\text { No By-elections (A Vacant Is } \\
\text { Party-list) }\end{array}$ & Usually Filled According to the \\
\hline & Legislative Term & Filling the Expiration & \\
\hline
\end{tabular}

Source: Authors.

Notes:

*First Loser Margin Rate $=\frac{\text { The Candidate Votes }}{\text { Representa tive }- \text { Elect Votes }} \times 100 \%$

Table 3. Parties' Votes and Vote-winning Rate in House of Representatives Elections during Period of LDP-Komeito Coalition

\begin{tabular}{|c|c|c|c|c|c|c|c|c|}
\hline \multirow{2}{*}{$\begin{array}{l}\text { Election } \\
\text { Party }\end{array}$} & \multicolumn{2}{|c|}{1996 (Before Coalition) } & \multicolumn{2}{|c|}{2000} & \multicolumn{2}{|c|}{2003} & \multicolumn{2}{|c|}{2005} \\
\hline & Ordinary Districts & PR Districts & Ordinary Districts & PR Districts & Ordinary Districts & PR Districts & Ordinary Districts & PR Districts \\
\hline LDP & $\begin{array}{c}21,836,096 \\
(38.62 \%)[169]\end{array}$ & $\begin{array}{c}18,205,955 \\
(32.76 \%)[70]\end{array}$ & $\begin{array}{c}24,945,806 \\
(40.97 \%)[177]\end{array}$ & $\begin{array}{c}16,943,425 \\
(28.31 \%)[56]\end{array}$ & $\begin{array}{c}26,089,326 \\
(43.85 \%)[168]\end{array}$ & $\begin{array}{c}20,660,185 \\
(34.96 \%)[69]\end{array}$ & $\begin{array}{c}32,518,389 \\
(47.77 \%)[219]\end{array}$ & $\begin{array}{c}25,887,798 \\
(38.18 \%[77]\end{array}$ \\
\hline NK & - & - & $\begin{array}{c}1,231,753 \\
(2.02 \%)[7]\end{array}$ & $\begin{array}{c}7,762,032 \\
(12.97 \%)[24]\end{array}$ & $\begin{array}{c}886,507 \\
(1.49 \%)[9]\end{array}$ & $\begin{array}{c}8,733,444 \\
(14.78 \%)[25]\end{array}$ & $\begin{array}{c}981,105 \\
(1.44 \%)[8]\end{array}$ & $\begin{array}{c}8,987,620 \\
(13.25 \%[23]\end{array}$ \\
\hline DP & $\begin{array}{c}6,001,666 \\
(10.61 \%)[17]\end{array}$ & $\begin{array}{c}8,949,190 \\
(16.10 \%)[35]\end{array}$ & $\begin{array}{c}16,811,732 \\
(27.61 \%)[80]\end{array}$ & $\begin{array}{c}15,067,990 \\
(25.18 \%)[47]\end{array}$ & $\begin{array}{c}21,814,154 \\
(36.66 \%)[105]\end{array}$ & $\begin{array}{c}22,095,636 \\
(37.39 \%)[72]\end{array}$ & $\begin{array}{c}24,804,786 \\
(36.44 \%)[52]\end{array}$ & $\begin{array}{c}21,036,425 \\
(31.02 \%)[61]\end{array}$ \\
\hline $\mathrm{CP}$ & - & - & $\begin{array}{c}1,230,464 \\
(2.02 \%)[7]\end{array}$ & $\begin{array}{c}247,334 \\
(0.41 \%)[0]\end{array}$ & $\begin{array}{c}791,588 \\
(1.33 \%)[4]\end{array}$ & - & - & - \\
\hline NPS & $\begin{array}{c}727,644 \\
(1.28 \%)[2]\end{array}$ & $\begin{array}{c}582,093 \\
(1.04 \%)[0]\end{array}$ & - & - & - & - & - & - \\
\hline NFP & $\begin{array}{c}15,812,326 \\
(27.97 \%)[96]\end{array}$ & $\begin{array}{c}15,580,053 \\
(28.03 \%)[60]\end{array}$ & - & - & - & - & - & - \\
\hline LP & & & $\begin{array}{c}2,053,736 \\
(3.37 \%)[4]\end{array}$ & $\begin{array}{c}6,589,490 \\
(11.01 \%)[18]\end{array}$ & - & - & - & - \\
\hline UDR & $\begin{array}{c}149,357 \\
(0.26 \%)[1]\end{array}$ & $\begin{array}{c}18,844 \\
(0.03 \%)[0]\end{array}$ & - & - & - & - & - & - \\
\hline SDP & $\begin{array}{c}1,240,649 \\
(2.19 \%)[4]\end{array}$ & $\begin{array}{c}3,547,240 \\
(6.38 \%)[11]\end{array}$ & $\begin{array}{c}2,315,234 \\
(3.80 \%)[4]\end{array}$ & $\begin{array}{c}5,603,680 \\
(9.36 \%)[15]\end{array}$ & $\begin{array}{c}1,708,672 \\
(2.87 \%)[1]\end{array}$ & $\begin{array}{c}3,027,390 \\
(5.12 \%)[5]\end{array}$ & $\begin{array}{c}996,007 \\
(1.46 \%)[1]\end{array}$ & $\begin{array}{c}3,719,522 \\
(5.49 \%)[6]\end{array}$ \\
\hline $\mathrm{JCP}$ & $\begin{array}{c}7,096,766 \\
(12.55 \%)[2]\end{array}$ & $\begin{array}{c}7,268,743 \\
(13.08 \%)[24]\end{array}$ & $\begin{array}{c}7,352,843 \\
(12.08 \%)[0]\end{array}$ & $\begin{array}{c}6,719,016 \\
(11.23 \%)[20]\end{array}$ & $\begin{array}{c}4,837,952 \\
(8.13 \%)[0]\end{array}$ & $\begin{array}{l}4,586,172 \\
(7.76 \%)[9]\end{array}$ & $\begin{array}{c}4,937,375 \\
(7.25 \%)[0]\end{array}$ & $\begin{array}{l}4,919,187 \\
(7.25 \%)[9]\end{array}$ \\
\hline IFR & $\begin{array}{l}3,663,917 \\
(6.4 \%)[9]\end{array}$ & $\begin{array}{c}1,147,077 \\
(2.06 \%)[0]\end{array}$ & $\begin{array}{c}4,031,026 \\
(6.71 \%)[16]\end{array}$ & - & $\begin{array}{c}4,165,176 \\
(6.99 \%)[12]\end{array}$ & - & $\begin{array}{c}3,242,078 \\
(4.77 \%)[18]\end{array}$ & \\
\hline $\begin{array}{l}\text { Source: Zenic } \\
\text { http://www sou } \\
\text { Notes: } \\
\text { 1. Initials: LI } \\
\text { Frontier P } \\
\text { Factions at }\end{array}$ & $\begin{array}{l}\text { irou (2005: 202); } \\
\text { nu.go.jp/senkyo/sen } \\
\text { P for Liberal-Demo } \\
\text { ty; LP for Liberal F } \\
\text { d Representatives. }\end{array}$ & $\begin{array}{l}\text { inistry of Inter } \\
\text { o_s/data/index.h } \\
\text { atic Party; NK } \\
\text { ty; UDR for the }\end{array}$ & $\begin{array}{l}\text { New Komeito; } \\
\text { lon of Democrat }\end{array}$ & m; SDP & $\begin{array}{l}\text {; CP for Conse } \\
\text { al Democratic }\end{array}$ & $\begin{array}{l}\text { e Party; NP } \\
\text { JCP for Jap }\end{array}$ & $\begin{array}{l}\text { New Party Sa } \\
\text { mmunist Party }\end{array}$ & $\begin{array}{l}\text { 2007, from } \\
\text { NFP for New } \\
\text { r Independent }\end{array}$ \\
\hline $\begin{array}{l}\text { 2. The values } \\
\text { 3. The total } s\end{array}$ & $\begin{array}{l}\text { parenthesis () sta } \\
\text { ts of House of Rept }\end{array}$ & $\begin{array}{l}\text { or vote shares } \\
\text { ntatives: } 500 \mathrm{st}\end{array}$ & $\begin{array}{l}\text { the values in bra } \\
\text { in } 1996,480 \text { sea }\end{array}$ & $\begin{array}{l}\text { stand for } p \\
000 \text { and ther }\end{array}$ & eat-winning. & & & \\
\hline
\end{tabular}

